\title{
Prostate Cancer pT2 TNM Finding v6 and v7
}

National Cancer Institute

\section{Source}

National Cancer Institute. Prostate Cancer pT2 TNM Finding v6 and v7. NCI Thesaurus. Code C48236.

Prostate cancer confined to the prostate gland. (from AJCC 6th and 7th Eds.) 